\title{
論文要旨と審査結果
}

\section{Geography and Trade in Central Asia}

\author{
学位申請者氏名：Elvira Stankulovna Kurmanalieva
}

\section{I. 論文要旨}

本論文において申請者は、中央アジアの貿易を分析対象としてとりあげ、中央アジアの 貿易パターンは、天然資源に関する強い比較優位と、地域的統合の欠如と、貿易を促進す る政策の欠如の結果であることを示した。そのねらいは次の三つである。

（1）潜在的貿易についてのグラビティ・モデルに基づくこれまでの計量経済学的方法を改 善し、「中央アジアの謎」ともいうべき域内貿易の減少傾向を解明する。

（2）類別の貿易データにより中央アジア内の比較優位を分析する。

（3）輸送に関する規模の経済を数值化することにより貿易の費用を計算する。

これらの分析に共通しているのは、規模の利益があることを想定しているということで ある。その意味で Krugman らによって提案された「新しい貿易理論」に則った研究となっ ていることを特筆しておきたい。

中央アジアの域内貿易は 1996 年から 2005 年にかけて趨勢的に下落している。本論文の 第 2 章では、グラビティ・モデルを用いて、中央アジアの貿易の総額と域内取引の額の推 定值を求め、この推定值を潜在的に可能な貿易量とみなし、これと現実の貿易量とを比較 した。グラビティ・モデルの推計にあたってはスペシフィケーションと omitted variable bias とに十分に注意を払い、また missing observation の存在が重大な問題であるという認 識のもとに、この問題を処理する方法を検討した。最終的には Hausman-Taylor 法と Stochastic Frontier 推計法を用いた。

計測の主な結果は、中央アジアでは、域内貿易については、貿易量が潜在的に可能な量 を下回る傾向が近年強まっているのに対し、域外との貿易については潜在的可能量をむし ろ上回る傾向がみられる、というものであった。

なぜこのような傾向がでるのか。この地域は天然資源が豊富なので、これを域外に輸出 し、域内では工業品を輸出入し、場合によってはいわゆる「産業内貿易」も行う、という 可能性が考えられる。これは、域内では各国間で産業構造の補完性が高ければ高いほど、 また域外貿易についてはその貿易総額に占める割合が低いほど、また域外との代替性が高 いほど、域内の貿易は経済厚生への効果が大きい、ということを意味する。「新しい貿易理 論」どおりの貿易、すなわち規模の経済がある状態での貿易の場合は、関税同盟や自由貿 易協定などは域内の経済を活性化させる。しかも、製造業の割合が高いほど、そのような 
利益、すなわち「産業内貿易」の利益も大きくなる。以上のような視点から、第 3 章では まず産業内貿易をチェックするために Grubel-Lloyd 指数を計算した。ついで、独占的競争 のもとで似たような生産要素の賦存状況にある場合には産業間貿易が行われやすいという 仮説を検証する Helpman テストを行った。以上の分析から、中央アジアの貿易は域外も域 内も、天然資源の賦存によって支配されていることがわかった。キルギスタンのみについ ては、独立後の非常に早い時期から自由貿易政策をとっていたこともあって、比較優位の パターンが多少現れつつある。しかし、他の中央アジア諸国については対域内でも対域外 でも天然資源の輸出が中心である。このように中央アジア諸国間で、補完性が非常に低い のは、これらの国々の輸出入の構造が相互にマッチしていないことを示している。

Grubel-Lloyd 指数は産業内貿易が非常に低い割合にあることを示し、Helpman テストも産 業内貿易がほとんどゼロであることを示した。

最後のテーマは域内の輸送コストについてである。中央アジアの諸国は貿易の際に隣国 に依存しなければならず、そのような地理的な条件と不十分なインフラストラクチャーの ために国際貿易のための輸送には困難が付きまとう。このような条件のもとでは、域内で お互いに貿易をするのがもっとも容易である。第 4 章ではこのような意識のもとで中央ア ジアの域内の輸送コストの分析を行った。手法としてはオペレーションズ・リサーチの分 野の「最短距離数え上げ法」を国際貿易の密度の問題に応用している。この手法の経済学 の分野への応用は初めてである。密度が高ければ、輸送に規模の利益が働く。しかし、分 析の結果は中央アジアでは規模の利益を享受できていない、すなわち貿易量が低すぎる、 というものであった。域内の貿易が少ないことが輸送コストを高くし、それがまた域内の 貿易の足をひっぱるという悪循環がみられる。そして貿易構造を変えることによって域内 の工業品の貿易を増やすという望みも実現は難しい。これらの諸国は天然資源が豊富であ るために、古典的な比較優位の原理からすれば、貿易を自由化しても貿易は天然資源中心 にならざるをえないからである。

本研究の成果はすでに共著の本の一部として公表される予定であったり（下記の 1)、す でに論文として公表されている（下記の 2)。本研究の一部ではないが、そのほかにも学位 申請者の研究ですでに公表されたものは数点ある。

申請者の公表論文リスト

1) Kurmanalieva. E and Z. Parpiev (2009) “Prospects for Central Asia' s Regional Trade: Product-Level Assessment" in: Taniguchi, K (ed) International Trade Policy in Uzbekistan and Asia, Palgrave Macmillan (forthcoming).

2) Kurmanalieva, E (2008) “Empirical Analysis of Kyrgyz Trade Patterns" , Eurasian Journal of Business and Economics 1(1), 83-97.

3) Kurmanalieva, E and L. Liu (2008) "Impact of Financial Services Trade Liberalisation on Capital Flows: The Case of China's Banking Sector” , in Barry 
Eichengreen, Charles Wyplosz, Yung ChuI Park (ed) China, Asia, and the New World Economy, Oxford University Press.

4) Kurmanalieva, E and Z. Parpiev (2007) "Geography and Trade in Central Asia", EERC Working Paper, research grant RO6-085.

5）大来洋一、エルビラ・クルマナリエバ（2006）「社会保障と老後のリスクと貯蓄」『季刊 家計経済研究』、(財) 家計経済研究所、No.72（2006 年 Autumn 号）、98-105 頁。

6) Kurmanalieva, E and H. Montgomery and J. Weiss (2005) "Poverty Reduction and Microfinance: A Review of the Evidence" in John Weiss (ed), "Poverty Targeting in Asia” . Edward Elgar Publishing.

\section{II. 審査結果報告}

審査委員 : 主査 大来 洋一

委員 大山 達雄

委員 カリアッパ・カリラジャン

委員 諸星 穂積

委員 ジェームズ・ローズ

本論文の最終報告に引き続き、平成 20 年 9 月 24 日（月） 16 時 50 分より審査委員会が 開催された。審査委員は大来洋一教授（主査）、Jim Rhodes 教授（副査）、諸星穂積教授 （副査）、大山達雄教授、Kaliappa Kalirajan 教授の 5 名であった。

全体として、申請者のオリジナルなアイディアが随所に認められ、理論、手法とも高度で あると評価できるという意見が多かった。

コメントとしては、

1. 序章の中で結論的な部分がある一方、結論として独立した章がない。

2. Grubel-Lloyd 指数や Helpman テストを用いたことは悪くないが、これらの手法に 限界があることを指摘した文献もあるので、きちんと触れておく必要がある。

3. 引用された文献のいくつかがすでにジャーナルに公表されているのに、ワーキン グ・ペーパーの段階のものが reference に載せられている。

4. Grubel-Lloyd 指数や Helpman テストに代わる、オリジナルな指数やテストを編み だせるとなおよかったのではないか。

5. 最近では 3 つぐらいのほとんど関連のないエッセイを並べる形式の博士論文がはや りであるのに対し、かつては複数の章が一つのテーマのもとでお互いに関連した形 のものが普通であった。申請者の論文はその中間にあるようにみえるが、中途半端 でないほうがよい。 
6.そのほか、用語や notation などについて細かいコメントがあった。

上記のコメントに対して、純粋に感想であるものを除き、著者は直ちに対応した。すな わち必要な修正を行い、修正稿を提出し、主査の最終確認を経た上で各審査委員の了解を 得ている。

この最終版をもって審査委員全員は本論文が本学博士論文として妥当であることを認め た。 